\title{
The Integration of Peace Education in Reading Comprehension Lessons in Primary Schools
}

\author{
Hanna Onyi Yusuf \\ Curriculum Section, Faculty of Education, Ahmadu Bello University, Samaru-Zaria, Nigeria \\ Email: hannayusuf@yahoo.com
}

\begin{abstract}
The paper examines the role of Peace Education in the primary School Curriculum. It also looks at the goals and tenets of Peace Education that can be integrated into the reading comprehension lessons in primary schools. The paper raised some challenges that English Language teachers may face in teaching some of the tenets of peace education and suggests possible ways of overcoming these challenges. The paper concluded with the need for English Language teachers to be more child-centred, innovative and creative in their teaching approach for more meaningful learning in order to achieve the desired results. The paper also suggests the need for curriculum Planners to include tenets of peace education in the list of titles for prose and poetry in primary school curriculum.
\end{abstract}

Index Terms -integration, peace, education, reading, comprehension, primary, school

\section{INTRODUCTION}

Peace Education to many Scholars such as Burns \&Aspeslaugh (2002), Bar-Tal (2002), Adams (2000), Harris \&Marrison (2003), Odejobi \&Adesina (2009) is essentially about understanding the nature of conflict at various levels from personal to global, studying the causes of war and human aggression, exploring a range of awareness of the rights and responsibilities of individuals and groups in the world.

Since the $20^{\text {th }}$ century, peace education programme around the world have represented a spectrum of focal themes. In Japan for instance, peace education targets issues of nuclear disarmament, militarism, in Australia, peace education focuses on challenging ethnocentrism, cultural diversity; in the United States, peace education is concerned about prejudice, violence and environmental issues, while in Africa, the focus is on hunger, poverty and starvation. Today, there is a great concern about the issue of peace world wide due to its continuous and constant threat to human existence. Education appears to be the means to move the world from a culture of violence to a culture of peace and tranquillity.

\section{A. Purpose of the Study}

This position paper is specifically aimed at discussing the various ways peace education tenets can be integrated into reading comprehension lessons in primary schools. The paper is also aimed at highlighting some of the challenges that English Language teachers may face in teaching the tenets of peace education.

\section{B. Definitions of Peace Education}

From the general view point, peace education is the process of acquiring values, knowledge, attitudes, skills and behaviours necessary to live in harmony with oneself, others and the natural environment.

Harris and Synoth (2002) describe peace education as a series of teaching encounters that draw from people their desire for peace, non-violent alternatives for managing conflicts and skills for critical analysis of structural arrangements that produce and legitimize injustice and inequality.

Ajala (2003) defines peace education as the type of education that impacts in learners all norms, values and attitudes that can bring about a conducive environment for human living.

Peace Education aims to help students acquire skills for non-violent conflict resolution and to reinforce these skills for active and responsible action in the society for the promotion of the values of peace.

Adejobi and Adesina (2009) viewed Peace Education as a type of study that essentially inculcates discipline in people. It is that course of study that teaches people the past and present causes of conflict or wars noting the effects, and recommending ways of averting such social ills.

According to Oyebamiji (2001), Peace Education is the type of education that is meant to promote a set of values, attitudes, traditions, mode of behaviour and ways of life based on respect for life, promotion of non-violence through education, dialogue and cooperation, promotion of all human rights and fundamental freedom.

Ajala (2003) defines it as the type of education that impacts in learners all norms, values and attitudes that could bring about a conducive environment for human living.

Peace Education in my own view, is a process where people learn forms of creating a culture of peace, analyse the causes of violence and learn values and skills that are congruent with peaceful behaviour. Peace Education is the gateway that takes people to various avenues of learning to appreciate individual differences, but honestly and sincerely 
addressing, the imbalances. Accepting that other people have different ways of looking at the world and empathizing with such views, even, when they are contrary to one's own. Peace Education is actually a call for an inclusive approach to mutual co-existence and a holistic way of living. A holistic way of living implies to live in peace with others and with the environment in all perspectives. Peace Education is, indeed, the only available way to create a more peaceful world. It is the starting point from which one can work to change individual and societal thinking in order to give up violent approaches.

\section{Goals of Peace Education}

The common general goals of Peace Education, among others, according to Harris \& Synoth (2002) include the following.

To teach peace as a process

To foster change in order to make the world a better and more humane place; and to understand violent behaviour.

To diminish and or eradicate human ills ranging from injustice, inequality, prejudice intolerance abuse of human rights, environmental destruction, violent conflict etc to create a World of justice and peace, where all forms of fears will be relegated.

To mobilize pupils and teachers to take part in a campaign for change as a way of appreciating the riches of the concept of peace.

To promote the development and implementation of conflict resolution and peace making programmes for people of all ages equipping them with resources and skills that encourages values of constructive conflict resolution and peace making.

To investigate different concepts and examples of peace on a variety of levels from the personal to the entire globe.

To develop an understanding of peace in a state of being and as a process characterized by an absence of direct violence and presence of well-being and just relationships in the economic, socio-political and ecological spheres of life

To cultivate on people attitudes and values which will enable them to contribute towards some form of change, and to create skills enabling people to be able to utilize reflective thinking, through which they deepen their understanding of themselves and their connectedness to the lives of others.

To explore peace both as a state of being and as an active process for the promotion of a positive human relations.

To examine obstacles to peace at an individual, group, institutional and societal level; and to build self-esteem through constructive and non-hostile peer relationships.

\section{Importance of Peace Education}

The aim of Peace Education is to engender a commitment among people to a vision of structural peace in which all personal freedoms are legally protected from violence, oppression and indignity. To drive this to pupils, tenets of peace such as compassion, justice, fairness, objectivity, fair play, Love, kindness, peace, among others should be embedded in the reading comprehension passages. These, plus other activities combined with aspect of conflict resolutions, along with training in non-violent action(s) put the pupil (child) in the right-frame of mind. Peace education is about empowering people with skills, attitudes and knowledge to:

- build, maintain, and restore relationships at all levels of human interaction.

- develop positive approaches towards dealing with conflicts from the personal to the international.

- create safe environments, both physically and emotionally, that nurture each individual.

- create a safe world based on justice and human rights.

- build a sustainable environment and protect it from exploitation and war.

Peace education is based on a philosophy that teaches nonviolence, love, compassion, trust, fairness, cooperation and reverence for the human family and all life in planet. Peace education leads to peaceful living.

\section{The Language Teachers’' Role in Peace Education}

The following are some of the ways language teachers can function as peace educators.

* The language teacher must understand that multi-cultural multi-ethnic and multi-religious problems in society, are not to be dealt with in isolation or in bits and pieces but integrated in meaningful reading comprehension passages that can assist pupils to develop a culture of peace. Such titles as compassion, living in harmony, love, kindness and service to others, can help solve conflicts of tribal, religious, or other prejudices.

* The language teacher must be cognizant and wholly supportive of the basic nature and aims of peace education. $\mathrm{He} / \mathrm{she}$ must believe in the education that actualizes people's potentialities, in helping them learn how to make peace with themselves and with others, to live in harmony and unity with self, human kind and nature. The achievement of a unified, peaceful society both globally and within the nation, where citizenship is fostered and "unity in diversity" is recognized and practiced can be made manifest by the commitment of the language teacher to the basic aims of peace education.

* The language teacher should constantly keep in mind that the attainment of the goals of peace education is conditioned upon knowledge, volition and action. Unless these three are forthcoming, nothing will be accomplished. To this end, the language teacher must use his/her initiatives, volition and willpower to develop qualities such as tolerance, 
respect and appreciation of others, being fair and open minded, being able to consider other points of view, and looking beyond his/her own self interest. In other words, the language teacher must be sincerely free of any form of prejudice.

When a language teacher becomes deeply and regularly involved in teaching the tenets of peace education in reading comprehension lessons, this can cause him/her (the teacher) to take a long, deep look at his values or beliefs. Clearly, it can center a person on one's own thoughts, vows, and deeds. In order to be a good role model to pupils, the teacher has the opportunity of transformation and change of the inner self. Then the pupils can be helped to feel and understand who a peaceful person is, who a peace maker is etc and then the teacher will have a powerful, positive influence on hundreds and thousands of children, and youths.

\section{A. Challenges of Language Teachers in Implementing Tenets of Peace Education in Reading Comprehension Lessons and Possible Solutions}

- Lack of creativity

A language teacher should be creative especially in the reading comprehension aspect of language study. This is because children are bored when a subject, topic lacks the creativity to keep them aptly attentive. When the comprehension text lacks these attributes, the responsibility then falls on the teacher who should inject intriguing tit-bits momentarily, and make the comprehension lesson enjoyable. For instance, a comprehension lesson titled "kindness" should include some practical examples of individuals demonstrating kindness to one another. Children should be made to dramatise the virtue of kindness as contained in the passage. When a teacher falls short of these expectations, the goal of reading comprehension with tenets of peace education is defeated.

- Poor command of English Language

Many Nigerian primary school teachers are not competent to teach effectively in English language. For example, Gamut's (1985) cited in Yusuf (2010) survey of English Language teaching conditions revealed $74 \%$ out of the 70 teachers studied could teach more effectively in Nigerian Language than they could in English Language. This type of situation compounds pupil's problem of acquiring English as a second language. Teachers should make conscious efforts to improve their level of competence in English Language by going for further training. They should also attend regular workshops, conferences and seminars.

- Time

Time here is related to portion of time belonging to particular events or situation, and this applies to the classroom situation. On one part, the teacher has a lot to do within so short a time. He marks assignments, teaches, goes round to correct erring ones, attends to special pupils - slow writers, sluggish learners etc. By the time, it is time for reading comprehension lessons, an aspect that does not only enhance pupils' language proficiency but also exposes them to basic and pertinent peace virtues, he (the teacher) is already worn out.

This affects the learner too. Teachers should create time for children to relax in between lessons. Teachers should also adopt effective time management skills that will help them accomplish their task successfully.

- Unavailability of "peace" related titles in reading comprehension passages.

In most primary English text books, comprehension passages are titled differently. Such titles include Air travel; Birthday parties, Train journey, visit to the zoo etc. There are hardly any titles with tenets of peace education.

It is recommended that comprehension passages should include peace tenets such as "kindness", "love", "peace", "respect" and "dignity", among others. When children, from early age learn how to live peacefully, they will abide by it for the rest of their lives, and the society will be a more peaceful place to live in.

- Poor teaching methods

Most English language teachers do not have the knowledge of the appropriate method/technique to use in teaching children reading comprehension (Yusuf 2009). Reading comprehension lessons can always be meaningful if teachers encourage and stimulate students to always make use of their relevant schema (i.e background knowledge/experience) to make and confirm predictions as they read the reading comprehension texts. Meaning does not always reside in the text. The reader has to activate his/her schema to make meaning out of print. The language teacher needs to guide children to achieve this by using interactive activities, active participation and collaboration and co-operative teaching/learning techniques. Teachers should use dramatization, miming, demonstration, pair reading, group work and interactive question and answer sessions. Teachers should encourage pupils to perform different activities before, during and after reading to enhance language proficiency.

- Lack of reading specialist teachers

In most primary schools, there are no specialist reading teachers. The English Language teacher assumes a dual role i.e as a language teacher and a reading teacher. Since the language teacher is not trained specially as a reading teacher, he/she is often found battling and trying to cope with the challenges in the classroom. In view of the fact that no education programme can rise above the quality of its teachers, the teacher factor becomes a critical one in the implementation of the tenets of peace education and the improvement of reading efficiency. More effort is needed to raise their level of competence. Language teachers lack training in peace education. Peace education tenets should be taught in teacher training colleges/colleges of education/universities.

- Lack of orientation/training 
Teachers lack training in peace education. Peace education tenets should be included in the teacher training curriculum. Regular workshops/orientation courses should be mounted for teachers to acquaint them with the latest and update information in the profession. Teachers should be encouraged to belong to professional Associations in Peace and conflict resolutions and Reading Associations such as RAN. They should also seek to update their classroom pedagogy through reading journals and attending relevant conferences.

- Lack of adequate teaching facilities

Most school lack adequate teaching facilities/materials for teaching. This tends to hamper or incapacitate teachers. Facilities/teaching materials such as overhead projectors, television set, DVD players, VCD players, tape recorders, pictures, posters, etc. should be provided in adequate quantities for teachers. Jingles on peace education, songs on peace education and drama or playlets on peace education need to be provided by schools/teachers to make learning more meaningful and interesting.

\section{B. Integrating the Tenets of Peace Education in Reading Comprehension Lessons in Primary Schools}

English language is a subject that is taught everyday on the timetable. Reading comprehension is one of the fundamental language skills children are expected to be exposed to all through their schooling. In view of this, young children need to be constantly inspired through meaningful reading comprehension lessons, to have a positive mental attitude, because their attitude will determine their altitude ultimately in life. No one needs to carry out any research to know that from infancy to this level of education, every child is supposed to know that aeroplanes fly in the air, ships ply the water ways, cars and trains on road and rails respectively. Unfortunately, most comprehension passages in pupils texts from primary $1-6$ are seen talking about those experiences. It is high time we made a u-turn. Now is the time to make children agents of peace. Children should read more about mutual co-existence, religious tolerance, respect for one another, good neighbourliness, love, caring and sharing, compassion, forgiveness, loyalty, piety, kindness, honesty, optimism, peace etc.

Children should be taught that a smiling face will win more friends than a frowning one. They equally need to know that whatever the human mind can conceive and believe, it can achieve. Therefore, they should be taught positive things about the world. They should be encouraged to conceive and believe that the world is a peaceful one. These virtues will help them to grow to become peace loving good citizens who will always dare to be the change they want to see in the world.

Samples of some reading comprehension passages developed by this researcher containing tenets of peace education are included in the appendix of this paper. Below is a demonstration lesson with one of such samples.

\section{A SAMPLE LESSON GUIDE (FOR PRIMARY 4-6)}

\section{Living in peace}

Tunji often takes advantage of his size and picks on smaller kids. Without the slightest offence from his classmates, he pounces on one. He does this with pride. The children now live in fear. He eats their food, collects their money and other valuables, and the children are afraid to report for fear of repraisal attack. But Uche was a kid with guts. Small and a constant victim of his brutality, Uche decided he will do something. He quietly orchestrated a plan with David. They called all the children in the class together and told them that the only way to deal with this kind of person is not to be annoyed. That, they should come to school and keep their food with another teacher in another class. Give him all their money to keep, then at break time, they will go there one after the other to eat and buy whatever they want in the canteen other than the place he usually sits to attack them. Uche did even more.

The next day, he went to their head teacher and reported him. The teacher came to the class with six other bigger boys. By their size, you could tell they are stronger than Tunji. So, whenever he tries to bully a younger or smaller kid, other big boys will stop him. After one week, Tunji changed, knowing fully well that if he ever tries something out, he will be dealt with severely by this six big boys.

The entire children became friends with the new boys while Tunji became an outcast. One day, he stood up in class and apologized to them all. He told them that what he felt now is really bad. That he now realized how bad the kids were feeling in his days of brutality. Till this day, the children live happily and in peace.

\section{Answer the following questions}

1. Why did the children live in fear?

2. Why is it that it is only Uche that went to report?

3. Why did the teacher bring six more boys to Uche's class.

4. How did Tunji learn his lesson?

5. What lessons could be derived from the passage?

6. Do you consider Tunji's acts of bullying as good or bad? Give reasons for your answer.

\section{Introduction}

Teacher should introduce the passage above by asking some pre-reading questions such as

a) what does it mean to live in peace?

b) Why do we need to live in peace?

c) What are the benefits of living in peace with our classmates, schoolmates and neighbours? 
d) What does the title of the passage suggest?

\section{Presentation:}

Step 1 Teacher should stimulate meaningful discussion on the passage through the above questions.

Step 2 Teacher should read the first sentence and ask the pupils what they think the passage is about.

Step 3 Teacher should read the first paragraph together with the pupils to confirm their predictions.

Step 4 Teacher should read the first sentence of the second paragraph and ask the pupils why "the teacher decided to come to the class with six bigger boys"

Step 5 Teacher should read the second paragraph with the pupils to confirm their predictions.

Step 6 Teacher should read the first sentence of the last paragraph and ask the pupils "why the entire class became friends with the new boys and Tunji became an outcast".

Step 7 Teacher should make pupils demonstrate and act a short playlet on the content of the passage.

Step 8 Teacher should discuss answers to the comprehension questions.

Evaluation: Teacher should discuss ways of making peace and what pupils can do to live in peace with one another. In addition, pupils should answer the questions after the comprehension passage.

Conclusion: Teacher should give pupils homework to list ways they can make or live in peace with their classmates.

\section{RECOMMENDATIONS AND THE WAY FORWARD}

- Orientation/training courses should be mounted for language teachers with emphasis on teaching the tenets/values of peace education.

- Language teachers need to be trained before they are allowed to teach in schools. The training should reach the university teaching staff as it is the base where reconstruction of ideas along this line is most viable.

- Curriculum planners should suggest activities that language teachers can expose their children to in order to achieve some of the peace education goals.

- Schools should be well equipped with adequate teaching facilities for effective and meaningful learning.

- Symposia, conferences, debates, seminars, talks and displays of instances of war and outcomes of peace should be encouraged in the teaching profession.

- Children need to be trained and encouraged to be part of the national peace building network where they can make meaningful contributions and become part of the solutions themselves. Now is the time to make children agents of peace.

- English language teachers should create the awareness through relevant reading comprehension passages that peace education is not just a concept that needs to be grasped but it is actually a vision, mission and a way of life which requires commitment on their part.

- English language teachers should be more child-centred, innovative and creative in their teaching approach for more meaningful learning in order to achieve the desired results.

- Curriculum planners should ensure that the tenets of peace education such as kindness, loyalty, honesty, love, optimism, compassion, peace etc are included in the titles for prose and poetry in the primary school curriculum.

\section{CONCLUSION}

The "seed" for building a culture of peace in Nigeria and in the world at large are the young children in primary schools, scattered all over the country/world, who through the integration of the tenets of peace education in their reading comprehension lessons, can have a good solid foundation upon which the nation/world can boast of a lasting culture of peace and tranquillity.

It is often said that if one wants to build a house, one should start with the foundation. The primary school in this regard, is the foundation and bedrock upon which other levels of education are built. In view of this, it is important for peace education to be introduced in the primary school curriculum to shape the personality, character and ethics of children at this level of education. Reading comprehension lessons should be the starting point. Curriculum planners and English Language text book writers should ensure that the tenets of peace education which aims at information, formation and transformation are integrated into reading comprehension passages to develop pupils to their fullest potentials.

\section{APPENDICES SAMPLES OF READING COMPREHENSION PASSAGES WITH TENETS OF PEACE DEVELOPED BY THIS RESEARCHER}

\section{APPENDIX 1}

\section{Selflessness}

Tobi looked worried after school. They were asked to buy a sketch pad for the fine Art class the next day, and the teacher made it clear that if anyone doesn't have, he/she will stay outside as long as the subject lasted. Tobi thought 
what to do; for his parents are away to Port-Harcourt. His uncle living across the street said he hadn’t any 350.00 to spare. The only option left was to go ask his friend Emeka living in the street opposite theirs.

He walked to his house but Emeka told him that the only money he has is 120 . Tobi wondered how he was going to manufacture an additional $\$ 230.00$. It was getting dark, so he walked home with mixed feelings, tears began to form in his eyes. Just as he was about to cross the road to his house, he saw a black wallet lying by the road side". Could this God answering my prayers?" he wondered. He looked behind, sideways, and ahead. Nobody was near. So, he picked it up.

First, he admired it. Then he opened it. "Money!:" he exclaimed. Looking at the pile of bills neatly arranged, he knew it was much money. He concluded he was going to count it when he got home. As he got home, he ran to his room and locked himself in his room. "One, two, three," he counted. The money was $\$ 12,450.00$. He was happy he found money at last to buy not only the sketch pad but other things. He looked out of the window and saw an old man asking people something. He thought the man maybe lost. So, he went out to help. "Hello grandpa, are you ok?", he inquired. "No little man. I think I just lost my wallet. Did you find anyone around here please?".

Tobi thought whether to return the wallet, and that means not buying the sketch pad. "The wallet did belong to this old man", he thought again. "Here grandpa", he said handing him the wallet. "Is it this? "I picked it few minutes ago". The old man's face was very wrinkled but his expression was quite graceful. "Thank you my boy", the old man said. As Tobi was walking away toward his house, the old man called out. "My dear boy", and Tobi stopped. He gave him \#40 for his kindness, sincerity and selflessness.

\section{Answer the following questions}

If you were in Tobi's shoes, what would you have done?

a) Hold on to the wallet and spend the money on valuables?

b) Do as he had done: return the wallet to the deserving owner?

c) Go right ahead and remove $\$ 350.00$ for your sketch pad and leave the rest money on the side walk?

d) Would you have requested for money from the old man or test his sense of discretion as shown?

e) Go show your uncle that you have got money after all?

\section{APPENDIX 2}

\section{Ada, the little child of peace}

Little Ada and her mother spent Saturday afternoon cleaning out the kitchen. The mother took it upon herself to explain the function of each equipment to young Ada. She was intrigued. She tries putting to work some of the equipment: the electric and gas cookers, switch on the gas cylinder and off; set the light/flame to the acceptable mode; switch between electric current and gas freely without making mistakes; try toast some bread; blend some juice; manage the kitchen. She was grateful to her mother for everything. Indeed, she confessed it was her best moment spent in the home and with her mother ever. As the job wears them down, they sat at a stool and ate some of the food little Ada just prepared "if you continue like this my darling daughter, you will be one of the greatest chefs Nigeria will produce", her mother said.

She studied her mother closely and saw tears forming in her eyes. "Mummy! Are you ok!", she asked. Her mother nodded on the affirmative. She came down from her stool, with some tissue paper together and handed it to her. "You are the best mum in the world and you are very beautiful", she said. "Is it daddy?"

For some time now, Ada had noticed that her father seldom come home early, and when he comes, he goes straight to bed. They don't eat together anymore. No more movies. He no longer helps her to do her homework or ask her who offended her in school. Little Ada knew that that is what is making mother to sob. She left the kitchen in a hurry. She went straight to daddy's room. This time her father was awake, with the Saturday paper in his hand. "Good morning daddy", she greeted. Her father invited her for a hug but she declined. He made to catch her but she ducked. He finally grabbed her but she wriggled out of his hold. "Leave me alone," she yelled.

"Ok princess, what is it this time" her father asked. "You don't seem to love mummy anymore. She is crying in the kitchen. Now go and talk to her". He looked at his daughter and thought for a moment." My daughter just four years, saying this? Her mother must have gotten into her head."

"Alright little mum, I will go talk to her later" "No dad. Right now" she replied. Her father stood up although reluctantly and strolled through to the kitchen. He grabbed his car keys in a way that Ada didn't notice. The next thing she heard was a car engine buzzing. She rushed outside and saw her father driving off. In less than ten minutes he was back. She could see very beautiful flowers at the back of the car. "Where is mummy?" "In her room, upstairs". He walked through the stairs to his wive's room, little Ada following behind. He knocked at the door. "Mum, open the door", she cried. When the mother heard her, she opened the door. She was not pleased with Ada because she was with her father. "What is this Ada?" she asked. "Dad, say something", Ada said.

Her dad gave her the flowers and said he was really sorry for everything. That he never thought of doing anything to hurt her but Ada's mum rejected it. "Mum, please. Dad said he is sorry for everything”, Ada pleaded on her father's behalf.

Together, they embraced and from then on, peace reigned supreme in their house, thanks, however, to little Ada.

\section{Answer the questions}


1. What drove Ada to make her father apologize to her mother.

2. Do you think she is rude to her father?

3. Why do you think Ada wanted her father to make peace with her mother.

4. What would you have done if you were in Ada's shoes?

5. Why is it always good to make peace in the home?

6. What is the overall lesson learnt from this passage?

\section{APPENDIX 3}

\section{Responsibility}

After a tough week at school, Adamu is looking forward to the weekend. He comes home, drops his books on his table and lets out a long sigh: the joy of doing absolutely nothing. Sleeping, watching TV, some football games/matches, visit friends, and try out one of his video games he just acquired.

After supper that night, his father called him to his room. "I am travelling to Lagos tomorrow. There are people coming to the office tomorrow. You have to go stay there from around ten 0'clock till 4pm, and please as they come, deliver these envelopes to them one on one. Sorry for the pains"

Adamu knew what that meant... sitting still, concentrating, no watching his favourite team play. He moans inside. This isn't exactly what he had in mind for the weekend.

\section{Answer the questions}

1. Should Adamu pretend to be ill?

2. Should he suggest to the father to send for his friend or one of his staff?

3. Why do you think his father chose him and not anyone else?

4. What lesson can be derived from the passage?

\section{APPENDIX 4}

\section{Making up after a disagreement}

Amira and her friends - Chioma, Ada and Kemi love to tell stories of how their weekend went during break on Mondays. Maryam came to join them but they all kept mute. She noticed the quietness resultant of her coming to join them and she left. Earlier, Maryam told Amira's mother that she is too playful. A feat that has led her to be grounded. Meanwhile, Maryam seem to be the most intelligent and studious.

Two days later, a test was to be held by the maths teacher. Amira sat next to Maryam as they usually do. She bit her biro all the while the test lasted as she doesn't seem to know anything. Maryam felt pity for her. She knew that if she told her how to factorise one of the equations, she may be able to do rest. She told Amira the formula to question one, and she was glad. Before she could notice, Maryam was gone, but she was grateful to her for the gesture. She was able to do similar exercises. After the test, she walked up to her and knelt down before her. "I am sorry for the embarrassment the other day. I have come to realize that you are a friend indeed. Please, let us be friends again". Maryam pulled her up to an embrace, while Ada, Chioma and other friends looked on, happy again that she is in their friendship list again.

\section{Answer the questions}

1. What prompted Maryam to help Amira?

2. Why was Amira annoyed with Maryam?

3. Why was Maryam grounded?

4. What lessons can you learn from Amira and Maryam?

\section{APPENDIX 5}

\section{Let us live in peace}

Where the rivers of time

Are foul by native stress and strife, And man becomes his own enemy, Life is distraught And its colourful scenes

Are mared and stained By dark brown blots of violent blood.

Let us live in peace,

For here, like tenants in thatched huts, we dwell.

Soon, too soon, the tropic storm will out-blow the flickering heights of human life.

Our huts will fall.

In frailty upon the earth

Whereon, they rot,

And we in foul disintegration, 
Will be identified - with dust.

\section{Answer the questions}

1. Why is it necessary to live in peace?

(a) because the world should be peaceful

(b) soon, too soon, the tropic storm will out-blow the flickering heights of human life

(c) one day we will all die

(d) man is created to live in peace with one another

(e) all of the above

2. Explain the meaning of the sentence - "... let us live in peace, for here like tenants in thatched huts we dwell".

3. Give 5 reasons why we should live in peace.

\section{APPENDIX 6}

\section{Love}

Aisha can't believe that John is in her class again this session. Last session, John, made popular by his football skills, decided, for whatever reason, that Aisha would be his target. John continually made derogatory and demeaning remarks about her. Fortunately, not all the girls around thought John is as good, so Aisha had some people to turn to; the people John has attacked at one time or another. She thought that maybe this year would be different, but she was yet afraid.

John was delighted to see her "favourite" target back in class. Aisha had vowed not to cross paths with John this term and session. To worsen matters, Aisha's teacher had assigned them to the same science group for the laboratory, and the snag is that you dare not interswitch groups. The consequences are huge. Not prepared for such, she stayed in her group - with John.

Today is their first day at the lab, and as glad as Aisha thought she is, John is absent. She concentrated, and other girls too. She however didn't give much to it until her phone rang after school. Before this time, she had learned that John has an appointment with his optician.

Much to her amazement, it is John on the phone. He wanted to know if he can come and get the lab notes from her. Aisha was dumbstruck. "John! Calling me for help!"

\section{Answer the questions}

1. Should she scream at him to forget it?

2. Would you suggest she give him the wrong notes instead?

3. Agree to give him the notes if he will promise to quit bothering her?

4. Tell him it will cost him $\$ 500.00$ or more?

5. Name the lessons derived from the passage.

\section{REFERENCES}

[1] Adesina, A.D.O (2003). Correlates of gender, socio-economic background and performance among junior secondary school students using advance organizer learning strategy. Unpublished M.A. Thesis, Obafemi Awolowo University Ile-Ife.

[2] Adams, David. (2000). From the International year to a decade for a culture of peace and non violence. International Journal of Curriculum and Instruction Vol. 1 No. 2, 1-10

[3] Ajala, E.M. (2003). The influence of peace education on labour management relations in selected industries in Oyo State, Nigeria, Unpublished doctoral dissertation: Department of Adult Education, University of Ibadan.

[4] Akudolu, L.R. (2009). Assessing Peace Education Component of the Universal Basic Education in Nigeria through Social Studies Curriculum. Faculty of Education, Nnamdi Azikiwe University, Awka.

[5] Bar-Tal, Daniel. (2002). The elusive nature of peace education. In Gavriel Solomon and the world. 27-36 London: Lawrence Erlbaum Associates.

[6] Bar-Tal, D., (2000). The unique nature of the objectives of Peace Education in the elusive nature of peace education, P. 2

[7] Bar-Tal, D. (1999). The elusive nature of peace, in: A. Raviv, L., Oppenheimer \& D. Bar-Tal (Eds) How children understand war and peace (San Francisco, CA, Jossey-bass).

[8] Burns, R and Aspeslagh, R. (2002). Concepts of Peace Education - A view of Western experience.

[9] Danesh, H.B. \& Danesh R. (2004). Education for Peace: breaking the cycle of violence. Paper presented at: African Civil Society Organization and development: re-evaluation for the $21^{\text {st }}$ century (New York, Office of Social and Economic Development, United Nations) p. 32-39.

[10] Danesh, H.B. \& Danesh R. (2004). Conflict-free conflict resolution (CFCR): process and methodology, Peace and Conflict Studies, 11(2), 55-84.

[11] Firer, R. (2002). The Gordian knot between peace education and war education, in: G. Salomon \& Lawrence Erlbaum) p. 56-62.

[12] Harber, C. (1996). Educational violence and education for peace in Africa - in PEACEMAKING AND CONFLICT RESOLUTION. Reading Booklet, p 151.

[13] Harris, I. \& Synoth, H. (2002). Conceptual underpinnings of peace education, in: G. Salomon \& B. Nevo (Eds) Peace Education: the concepts, principles, and practices around the world (New York, Lawrence Erlnaum) pp. 15-26

[14] Harris, Ian M. \& Marrison, Mary L. (2003). Peace Education. London: McFarland Company, Inc; Publishers.

[15] Hick, D. (1988). Understanding the field in education for peace: Issues, principles and practices in the classroom. London and NY: Routledge.

[16] Odejobi, C.O. \& Adesina, A.D.O. (2009). Peace Education and the School Curriculum JEP e Journal of Education Policy. 
[17] Olaosun, M.A. (1996). The effect of flowcharted advance organizers on retention and transfers of procedural skills in library information retrieval by fresh.

[18] Oyebamiji, M.A. (2001). Peace education as a process of preparing youth for nation building. Paper presented at the National Conference organized by Social Studies Association of Nigeria (SOSSAN) Western Zone, at Adeyemi College of Education, Ondo.

[19] Opprenheimer \& D. Bar-Tal (Eds) How children understand was and peace (San Francisco, CA, Jossey-Bass) pp. 27-58.

[20] Sathiparsad and Gray, (2002). Peace education, teaching young people constructive conflict - solution strategies in PEACEMAKING AND CONFLICT RESOLUTION. Reading Booklet, $p 182$.

[21] Staub, E. (2002). From healing past wounds to the development of inclusive caring: contents and processes of peace education, in: G. Salomon \& B. Nevo (Eds) peace education: the concepts principles, and practices around the world (New York, Lawrence Erlbaum) pp. 73-88.

[22] United Nations. (2004). International Decade for a culture of Peace and Non-violence for the children of the world. Accessed June 2006 at hpp://www3.uniesco.or/iycp/kits

[23] Vriens, L. (1999). Children, war, and peace: a review of fifty years of research from the perspective of a balanced concept of peace education, in: A Raviv, L.

[24] Yusuf, H.O (2009). "Strategies for improving the teaching of reading comprehension in primary school" Journal of Education Research and Development Vol. 4(3) 63-68 Zaria: A.B.U. Press.

[25] Yusuf, Hanna. (2010) "Teaching Reading Comprehension in Primary Schools" A Comparative study of Language Development and Vocabulary methods. A published Ph.D Dissertation, Mauritius: VDM Publishing House Ltd.

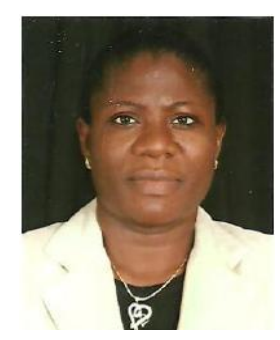

Hanna Onyi Yusuf was born in Ilorin, Kwara state in 1964. She has the following qualifications: Doctor of Philosophy (PhD) in Curriculum Studies (2005), University of Abuja, Nigeria, Masters Degree in Teaching English as a second language (1996), Ahmadu Bello University, Zaria, Nigeria, Bachelor of Education Degree in Language Arts, Ahmadu Bello University, Zaria, Nigeria, Nigerian Certificate in Education (English major) (1984) A.B.U. Zaria.

She has worked in the following organizations; Universal Basic Education Commission, Abuja, Nigeria as a Research Officer, Principal Project Officer and Chief Monitoring Officer 1989-2006. She transferred her services in 2006 to Ahmadu Bello University, where she currently works in 2006 as a lecturer in the Curriculum section of the department of Education, Faculty of Education. She teaches both undergraduate and post graduate students. She is a member of the internal and external Oral Examination panel for Masters and $\mathrm{PhD}$ degrees. She has supervised and graduated a few masters' degree and PhD students.

Dr (Mrs.) Hanna Yusuf is a member of the Reading Association of Nigeria (RAN), International Reading Association (IRA) and Curriculum Organisation of Nigeria (CON). She has some publications to her credit among which are: • Yusuf, H.O. (2009) "Strategies for improving the teaching of reading comprehension in primary schools." Journal of Education Research and Development. Zaria: ABU • Yusuf, H.O (1997) "Effect of Direct-Reading-Thinking Activity Approach on pupils' reading comprehension" Literacy and Reading in Nigeria, vol 7. • Yusuf, H.O (2001) "How to make and use a big book to teach reading in the primary school", UBE digest vol. 1 No.1. 